\title{
Strain buildup in the Northeast Japan orogen with implications for gigantic subduction earthquakes
}

Department of Earth and Planetary Science, the University of Tokyo, Hongo, Bunkyo-ku, Tokyo 113-0033, Japan.

E-mail: ikeda@eps.s.u-tokyo.ac.jp

Although recent GPS observations have made it possible to detect crustal strain precisely and extensively, we have not yet observed a whole cycle of strain buildup and release in orogenic zones by any geodetic methods. From the viewpoint of earthquake forecasting, we need to extract elastic strain from GPS-derived strain data. However, we do not have any (practical) geophysical method by which to discriminate between elastic and inelastic strains from GPS data. Based on the lesson from the 2011 Tohoku earthquake of Mw 9.0, we propose here that geological methods (and ways of thinking as well) should be used to estimate inelastic strain buildup quantitatively, thereby to evaluate present-day elastic strain buildup, which may eventually cause gigantic earthquakes. We review here a case history of the 2011 Tohoku earthquake, and present a global comparison with other gigantic $(M w \geq 9.0)$ subduction earthquakes in the world.

\section{Introduction}

Strain buildup: elastic or inelastic?

Crustal strain is built up in and around a subduction zone in association with interseismic coupling on the plate interface (Fig. 1). The elastic portion of the crustal strain is released during episodic decoupling events on the plate boundary; the remainder is accommodated as permanent (= inelastic) deformation mainly within the subduction-related orogenic zone, which is thermally weakened by magmatic heating (Fig. 1). Inelastic deformation within the subduction-related orogen includes brittle deformation associated with active intra-arc faulting in the upper crust especially near the volcanic front and on the backarc side (Fig. 1). Coseismic deformation is basically elastic, although damped by asthenospheric viscosity and thereby followed by postseismic deformation decaying exponentially with time.

Recent GPS observations have made it possible to detect crustal strain precisely in time and extensively in space. However, the duration of such advanced observations is too limited to cover a whole cycle of strain buildup and release in subduction-related orogens. Furthermore, we do not have any (practical) geophysical methods by which to discriminate between elastic and inelastic strains from GPSderived strain data. Any attempts to discriminate between elastic and inelastic strains using only geodetic data fall into a typical inversion problem. That is to say, solutions are not unique at all. In order to get a solution, transcendental knowledge (i.e., "model") is necessary, but it becomes more and more difficult to test the validity of the solution with increasing complexity of the model. Then, what can we do to avoid this deadlock?

For effective earthquake forecasting, we need to know how much elastic strain has been built up in a subduction zone. We propose here that geological methods should be used to evaluate inelastic strain buildup quantitatively, thereby to evaluate present-day elastic strain buildup, which may eventually result in gigantic earthquakes. In this paper, we review the process of strain buildup and release in the Northeast Japan (NEJ) arc on a geologic time scale, and discuss its implications for the occurrence of gigantic subduction earthquakes. A global comparison is also made with other gigantic $(\mathrm{Mw} \geq 9.0)$ subduction earthquakes in the world.

\section{Full strain release or partial strain release?}

In order to evaluate the seismic hazards of a subduction zone, we first need to know the maximum size of earthquakes that are produced from the plate interface (e.g., Ruff and Kanamori, 1980; Goldfinger et al., 2013). Obviously, instrumentally recorded earthquake data are

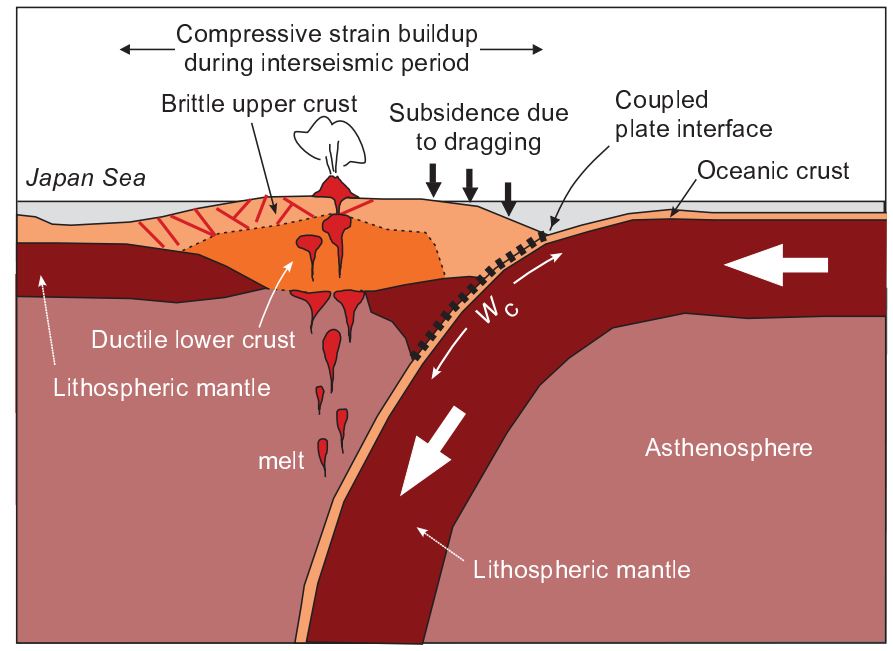

Figure 1. Schematic cross section of the Northeast Japan orogen. Rheological properties are simplified from Shimamoto (1989). $W_{C}$ denotes along-dip width of plate interface that is coupled in interseismic periods. Note that the Japan Sea is floored mostly by extended continental crust; the back-arc side of the NEJ arc was also extended in conjunction with the Japan Sea opening in early to middle Miocene time. 
not enough in terms of duration to evaluate the maximum size. Further problematic is the fact that some gigantic earthquakes ruptured a wide area of plate interface that encompasses a number of rupture areas of previous earthquakes as big as Mw 7 8, indicating that elastic strain has only been partially released in association with Mw 7 8 events. Examples include the 2004 Sumatra-Andaman earthquake of Mw 9.2 (e.g., Bilham et al., 2005) and the 2011 Tohoku earthquake of Mw 9.0 (discussed later in this paper).

Before going into details about the NEJ's case, let us define two terms: (a) full strain-release event and (b) partial strain-release event. In order to completely release the elastic strain that has been built up in and around a subduction-related orogen, it is necessary to rupture the whole down-dip width $\left(W_{c}\right)$ of the coupled plate interface (Fig. 1). Matsu'ura and Sato (1997) also suggested that the amount of slip $(D)$ on a plate interface increases with the length $(L)$ along strike of the rupture area, and becomes saturated as $L$ reaches $2 \sim 3$ times as long as $W_{\mathrm{c}}$. In this paper hereafter, we refer to such a slip-saturated event as a full strain-release event. If the strength of plate interface is constant, then the amount of $\operatorname{slip}\left(D_{\max }\right)$ at saturation is proportional to $W_{\mathrm{c}}$. The maximum moment release from a subduction zone, therefore, is expressed as

$$
\max M_{0}=\mu D_{\max } W_{c} L \propto W_{c}^{2} L,
$$

where $\mu$ is the rigidity. This indicates that the maximum amount of seismic moment release is proportional only linearly to the length, but squarely to the width, of coupled plate interface. Thus, the most important parameter in evaluating the maximum size of subduction earthquakes is the down-dip width of plate coupling (Ikeda et al., 2012).

We can estimate the maximum size of earthquakes from a subduction zone by the above equation and an empirical law by Fujii and Matsu'ura (2000). If $W_{\mathrm{c}} \sim 100 \mathrm{~km}$ as is approximately the case of the Nankai trough, $D_{\text {max }}$ is $\sim 5 \mathrm{~m}$ according to an empirical law by Fujii and Matsu'ura (2000). In this case, the maximum size is about Mw 8.7 even when the rupture propagates over the full length $(\sim 700 \mathrm{~km})$ of the Nankai trough. In contrast, if $W_{\mathrm{c}}$ is $200 \mathrm{~km}$ wide, then the amount of slip does not saturate until $L \sim 500$ $\mathrm{km}$, producing a gigantic earthquake of $\mathrm{Mw}$ $\sim 9.0$ at $L \sim 500 \mathrm{~km}$ as was the case for the 2011 Tohoku earthquake.

The most characteristic to a full strainrelease earthquake is that the rupture propagates to the free surface (= sea bottom), forming an "open end". Consequently, the distribution of slip in the full strain-release earthquake has its maximum at the free surface (Wu et al., 1991; Rudnicki and Wu, 1995), and the maximum amount of slip is about twice as large as that of an earthquake whose rupture surface is similar in size and geometry but does not reach to the free surface (e.g., Rudnicki and $\mathrm{Wu}, 1995)$. Therefore, the full strain release earthquake could produce larger surface deformation on the sea bottom and thereby result in a larger tsunami than the "constrained-end" earthquake does (Geist and
Dmowska, 1999). It should be emphasized that the physical essence of the Tohoku gigantic earthquake of 2011 is rather simple and can be understood in terms of full strain release.

\section{Geological setting of the Northeast}

\section{Japan arc}

Rheological structure of the Japan arc based on explosion seismology, heat-flow measurements, and laboratory experiments indicates that the back-arc region (west of the volcanic front) of NEJ arc, including continental slopes on the Japan Sea side, is mechanically very weak (e.g., Shimamoto, 1989; Fig. 1); only the upper $\sim 15$ kilometers of crustal rocks behave elastic, and ductile lower crust is underlain directly by asthenospheric mantle (e.g., Iwasaki et al., 2001). As described below, this zone of weakness was rifted and stretched during the Miocene back-arc spreading event, and coincides broadly with the distribution of active faults since the Pliocene.

The geologic structure of the Japan arc is a product of multiple phases of tectonic activity since the Mesozoic. The proto-Japan arc had been situated at the Eurasian continental margin until the late Oligocene, forming an Andean-type volcanic arc associated with subduction of the Pacific plate beneath Eurasia. Major geologic structures of the present-day Japan arc were formed during the period from the late Oligocene to the middle Miocene, when the proto-Japan arc separated from Eurasia in association with back-arc spreading (Fig. 2). The back-arc opening started in the north of the Japan Basin with the focus of spreading migrating southward (e.g., Kaneoka et al., 1992; Tamaki et al., 1992; Yoshida et al., 1995; Sato et al., 2004). Crustal extension within the NEJ arc occurred mainly in the later stage (16-13 Ma) of the Japan Sea opening (Sato, 1994), when the

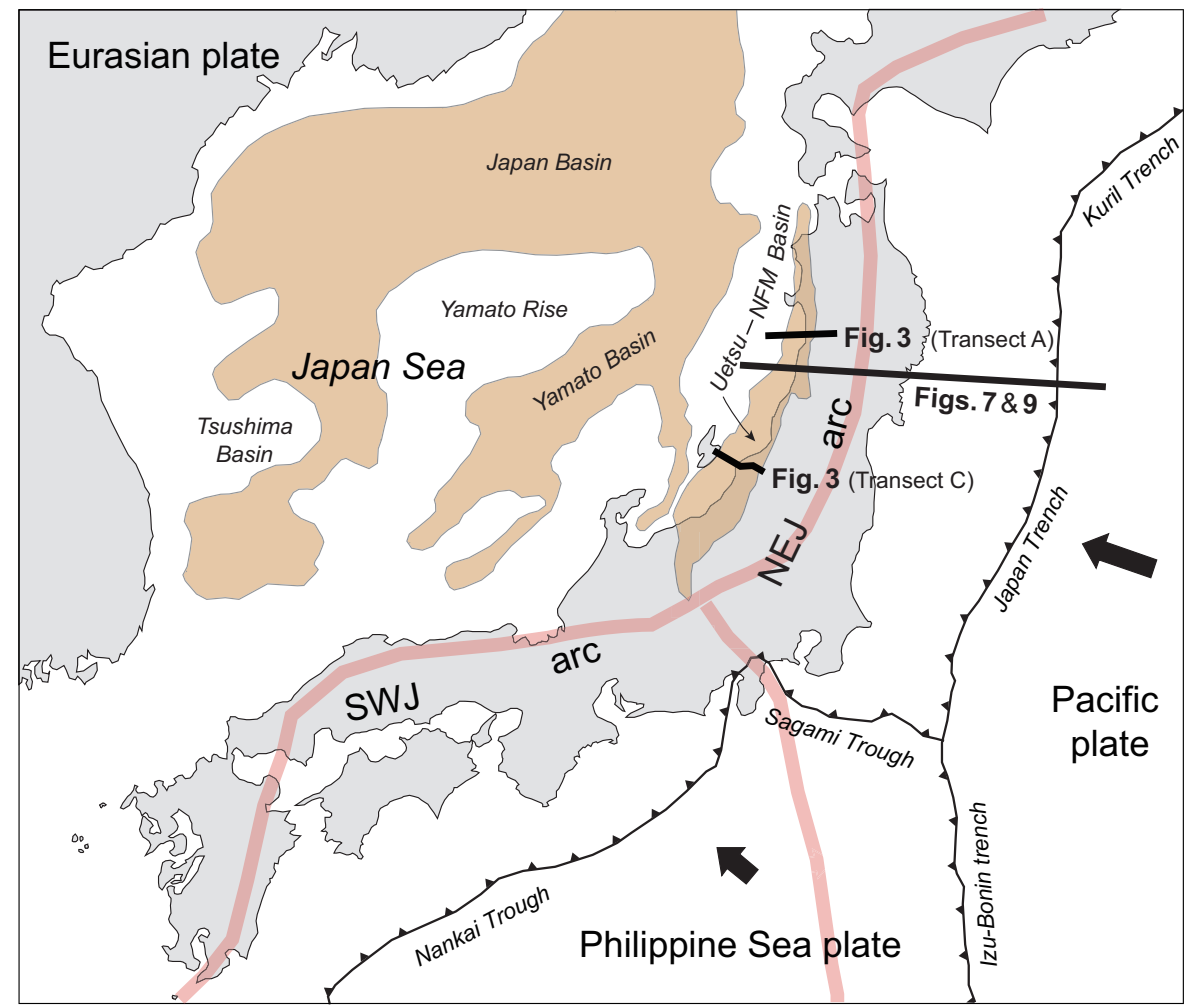

Figure 2. Regional setting of the Northeast Japan (NEJ) arc. Volcanic fronts are shown in pink solid lines. Light-brown colored areas indicate Early-Middle Miocene basins in the Japan Sea and the back-arc side of the NEJ arc. 
Southwest Japan (SWJ) arc rotated clockwise by as much as $\sim 50^{\circ}$ (Otofuji et al., 1985); the extension was particularly strong in the eastern margin of the Japan Sea, where the Uetsuand the Northern Fossa Magna (NFM) Basins developed (Fig. 2).

The style of the Miocene extension in the back-arc region of NEJ is highly asymmetric with a zone of concentrated extension along the Uetsu-NFM Basin (Figs 2 and 3). This extension zone is characterized by a break-away fault on the west, a rollover basement anticline on the east, and unusually deep $(\sim 10 \mathrm{~km})$ basins and strongly rotated fault blocks in between (Fig. 3; Okada and Ikeda, 2012), suggesting the existence of a large-scale detachment fault at a mid-crustal level beneath the extended zone. Such a style of deformation is best explained by Weissel and Karner's (1989) model, in which the brittle upper crust is capable of being deformed independently from the ductile lower crust and uppermost mantle (Fig. 4b). This model requires a detachment fault that mechanically decouples the upper crust from the lower crust and uppermost mantle; a beak-away fault soles into the detachment fault, forming a large-scale listric normal fault (Fig. 4b; Okada and Ikeda, 2012). The total amount of crustal extension across the NFM-Uetsu Basin is estimated by area-balancing restoration using seismic reflection, gravity, and surface-geologic data, and is found to be as large as 31-56 km (Fig. 3; Okada and Ikeda, 2012).

After $\sim 10$ Myr of tectonic quiescence following the opening of the Japan Sea, the NEJ arc has been subjected to crustal shortening perpendicular to the arc since $3.5 \mathrm{Ma}$ (Sato and Amano, 1991; Sato, 1994) or $5 \mathrm{Ma}$ (Moriya et al., 2008). The Pliocene and Quaternary contractional deformation is concentrated again within the UetsuNFM Basin (Figs 2 and 3), where Miocene and younger rift-fill sediments have been folded and faulted to form a fold-and-thrust belt (Matsuda et al., 1967; Sato, 1989). The total amount of crustal shortening across the NFM-Uetsu Basin during the past 3.5 5 Myr is estimated at 8 14 km (Fig. 3; Okada and Ikeda, 2012). As the asymmetric crustal extension model (Fig. 4b) proposed for the Miocene NEJ implies, under compressive stress field since the early Pliocene tectonic inversion, deformation could occur in the opposite
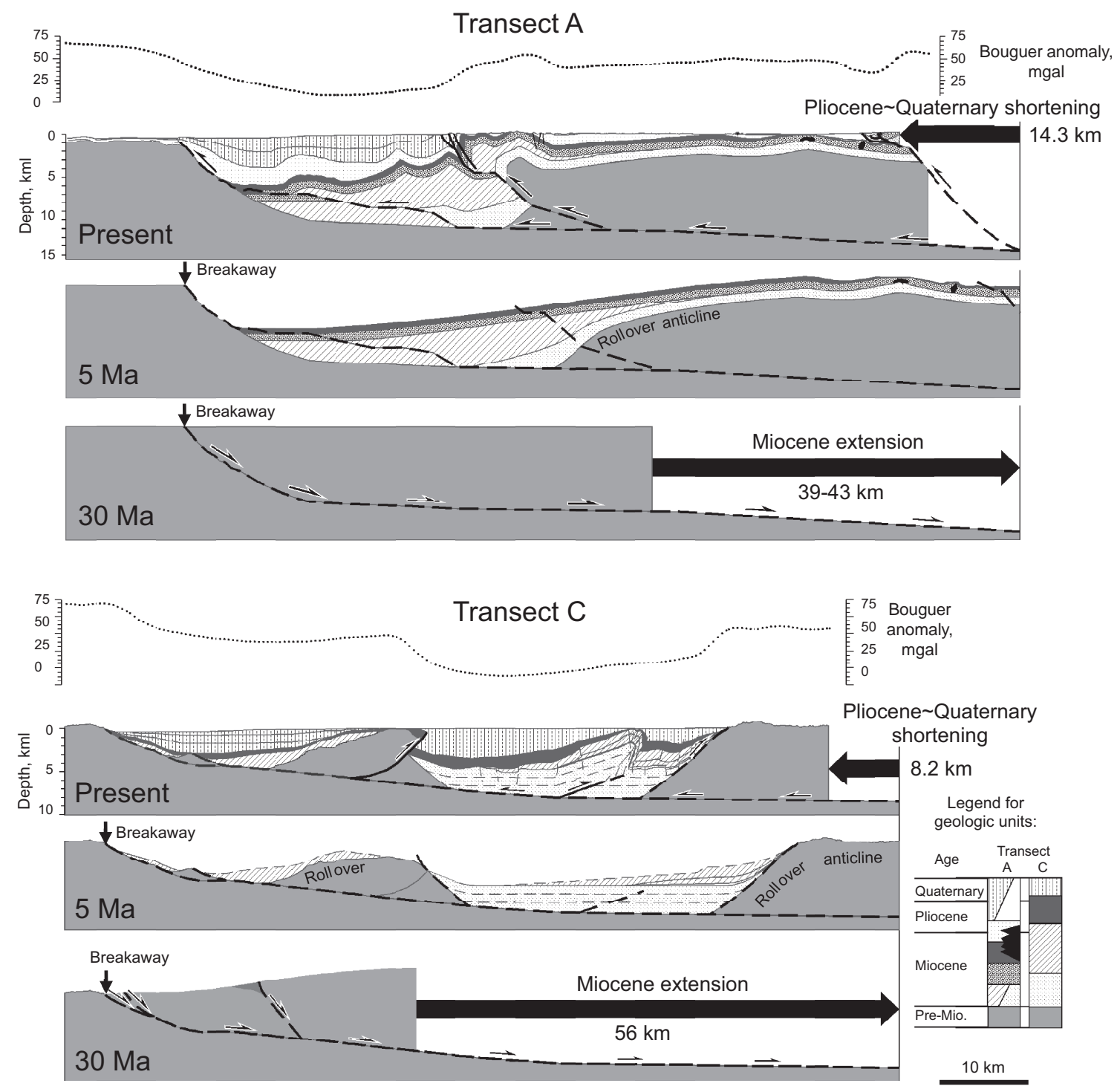

Figure 3. Present-day and restored geologic cross-sections along two transects across the Uetsu-Northern Fossa Magna Basin on the backarc side of Northeast Japan (simplified from Okada and Ikeda, 2012). See Figure 2 for location. Each set of four figures shows, from the top to the bottom, Bouguer gravity anomaly, present-day geologic section, restored geologic section before the Pliocene positive tectonic inversion, and restored geologic section before Miocene extension. 
(A) Symmetric rifting model

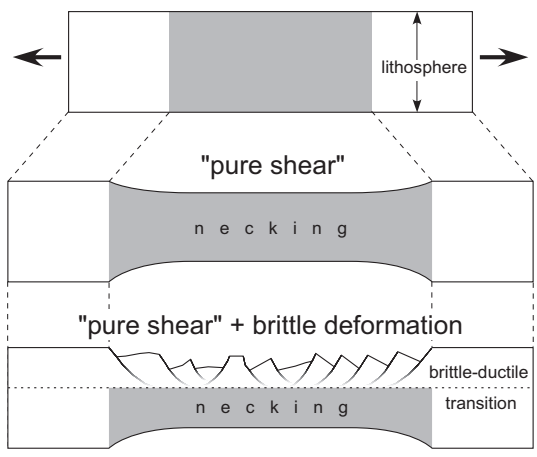

(B) Asymmetric rifting model

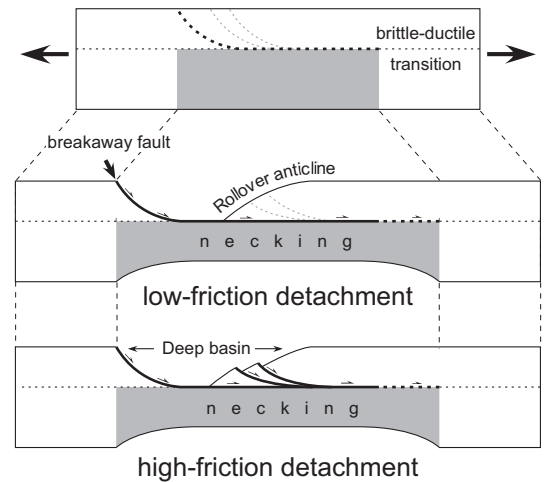

Figure 4. Symmetric and asymmetric rifting models (Okada and Ikeda, 2012). (A) Symmetric "pure shear" rifting model proposed by McKenzie (1978), and modified by Le Pichon and Sibuet (1981) with brittle deformation in the upper crust. (B) Asymmetric rifting model proposed by Weissel and Karner (1989), with modification into "high friction detachment" and "low friction detachment" cases by Okada and Ikeda (2012). Note that symmetric "pure shear" extension occurs below the brittle-ductile transition depth, whereas the upper crustal deformation is highly asymmetric. The asymmetric rift zone typically consists of a breakaway fault scarp on one side, a rollover basement anticline on the other side, and an abnormally deep basin in between. The asymmetric rifting becomes identical to the symmetric rifting with increasing friction on the detachment fault at the brittle-ductile transition. Note also that, under compressive stress field after positive tectonic inversion, deformation could occur in the opposite sense.

NEJ's back-arc is inelastic (permanent), and amounts to 8-14 km (Fig. 3). The amount of shortening outside the transects is estimated to be not more than a few kilometers (Okada and Ikeda, 2012). Because the present-day contractional tectonic regime started at 3.5 5 Ma (Sato and Amano, 1991; Sato, 1994; Moriya et al., 2008), the average rate of inelastic shortening is $3 \sim 5 \mathrm{~mm} / \mathrm{yr}$, whose value is one order of magnitude slower than the GPSderived shortening rate $(30-50 \mathrm{~mm} / \mathrm{yr})$. Therefore, we conclude that most of the horizontal strain that has been accumulating at abnormally-high rates in the past $\sim 100$ years is elastic; only a fraction $(\sim 10 \%)$ of the geodetically observed strain is inelastic, and is accommodated in the NEJ arc as permanent deformation (Ikeda, 1996, 2005, 2006; Ikeda et al., 2012).

\section{Vertical movements}

Discrepancy between long-term (geologic) and short-term (geodetic) observations exists also in vertical movements. Figure 6 (right) shows vertical crustal movements revealed by

sense both in the upper and lower crustal layers. It follows from this inference that lower-crustal strain could be distributed across a zone much wider than the Uetsu-NFM inverted basin (Fig. 4b), as has been observed by GPS (Fig. 5).

\section{Long-term versus short-term strain observations}

There has been much debate about discrepancies between longterm crustal deformation that have been observed by geological methods, and short-term crustal deformation that have been observed for 100 years by geodetic methods, over the Japan arc (e.g., Ikeda, 1996). Recent technological development in both geological and geodetic methods (e.g., space geodesy, geological dating techniques, etc.) has not reduced, but instead has enhanced, the discrepancies, as described below.

\section{Horizontal shortening}

Recent continuous GPS observations have indicated that the rate of horizontal shortening across the NEJ arc is in a direction almost parallel to the direction of convergence between the Pacific plate and Eurasia, and is as high as $30-50 \mathrm{~mm} / \mathrm{yr}$ (Fig. 5), which is about a half of the plate convergence rate $(80-90 \mathrm{~mm} / \mathrm{yr})$ at the Japan trench. The GPS-derived horizontal strain rate is on an order of $10^{-7} \mathrm{strain} / \mathrm{yr}$, which is broadly concordant with the horizontal shear strain rate derived from triangulation and trilateration survey data for the past $\sim 100$ years (e.g., Nakane, 1973). Thus, it is likely that the NEJ arc has been contracted at a very high rate for at least the last $\sim 100$ years.

On the other hand, geologically derived, long-term-averaged values of horizontal strain/shortening are one order of magnitude smaller than geodetically derived values. As already described, Pliocene-Quaternary horizontal shortening in the upper crust of the tide-gauge observations during the period 1955-1981 (Kato and Tsumura, 1979; Kato, 1983). Particularly striking in this figure is the fact that the Pacific coast of NEJ and Hokkaido has been subsiding at very high rates. Subsidence rate increases toward the trench, and reaches the maximum value as high as $\sim 10 \mathrm{~mm} / \mathrm{yr}$ (Fig. 6, right). Time series data at tide gauge stations along the Pacific coast indicates that the rapid subsidence has continued for at least 60-80 years (Fig. 8; Kato and Tsumura, 1979; Kato, 1983; Geographical Information Authority of Japan, 2010).

However, there is no evidence for long-term subsidence along the Pacific coast. Instead, late Quaternary marine terrace data indicate slow uplift (e.g. Koike and Machida, 2001; Ota and Saito, 2001). Figure 6 (left) shows height distribution of Last Interglacial ( 125 ka) shorelines. Since the eustatic sea level at the Last Interglacial maximum (LIM; $\sim 125 \mathrm{ka}$ ) is believed to be nearly the same as the present-day eustatic sea level, the height of a LIM shoreline relative to the present-day sea level approximately equals the amount of uplift during the past $125 \mathrm{kyr}$. Rates of uplift thus estimated are 0.1 0.5 $\mathrm{mm} / \mathrm{yr}$ along the Pacific coast of NEJ and Hokkaido. Such long-term uplift at moderate rates is not local but extensive over the NEJ (Fig.ure 6 , left), and is attributed to isostatic uplift due to crustal thickening, which in turn is caused mainly by (inelastic) crustal shortening possibly enhanced by magmatic underplating (Tajikara, 2004; Ikeda et al., 2012).

\section{Scenario of strain buildup and release}

\section{Interseismic coupling}

Observational data that we have reviewed so far indicate that most of the strain (both vertical and horizontal) that has accumulated in the NEJ arc during the last $\sim 100$ years at abnormally high rates is elastic. The cause of the elastic strain buildup is coupling on the plate 


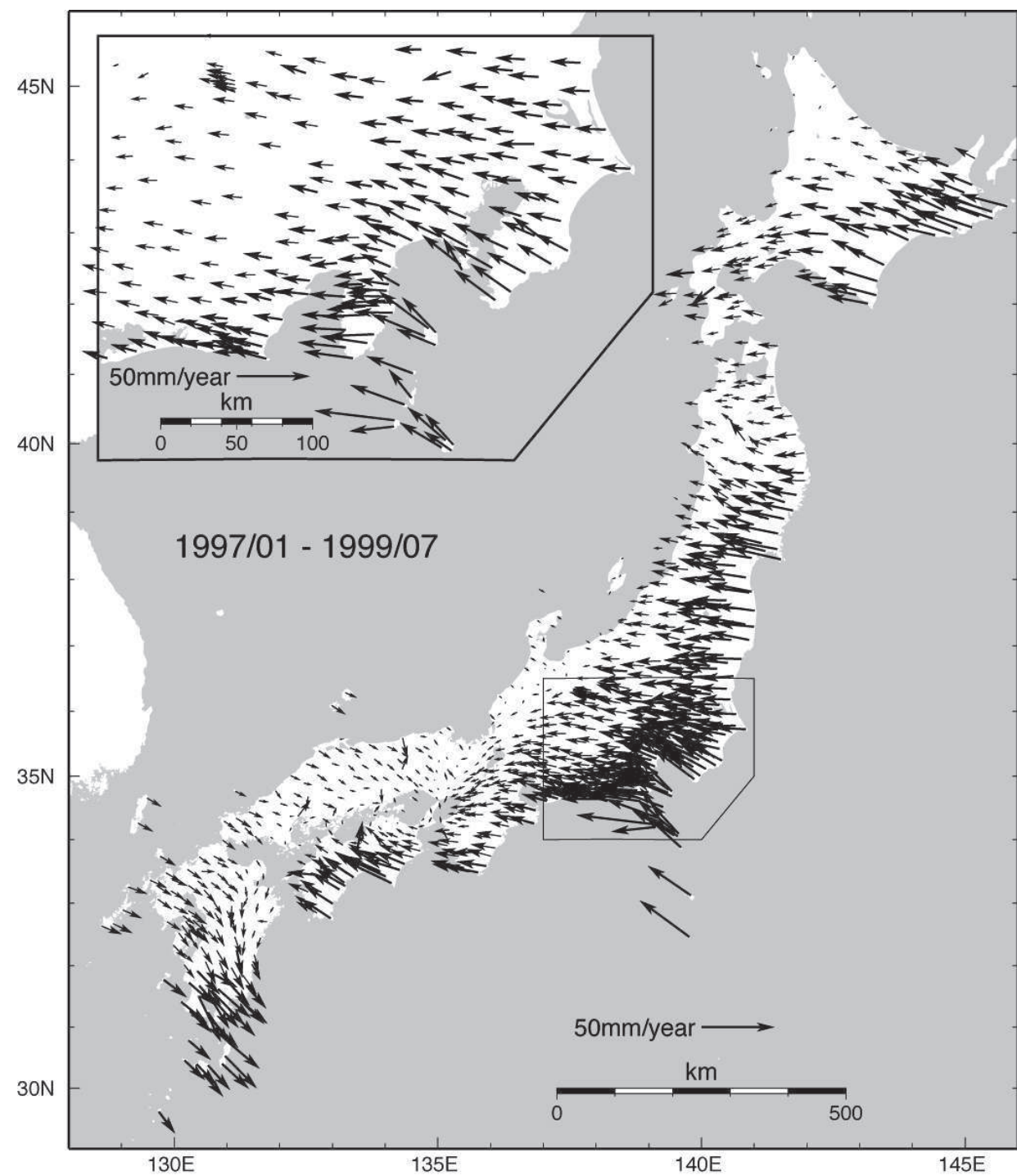

Figure 5. Horizontal velocity field revealed by continuous GPS measurements (Sagiya et al., 2000). Vectors are relative to the stable part of Eurasia. Inset magnifies Kanto area. Note high rates (30-50 mm/yr) of horizontal shortening across Northeast Japan.

interface; the overriding plate is shortened and dragged down by the subducting Pacific plate when the plate interface is mechanically coupled (e.g., Shimazaki, 1974). Fig. 7 shows calculated pattern of interseismic deformation along a transect crossing the Northeast Japan and the Japan Trench. The calculation was performed by the simple back-slip model (Savage, 1983) in an elastic half space. Since a calculated pattern of displacements is sensitive to the geometry of plate interface, we determined the geometry by using a simple elastic plate-bending model (e.g., Watts, 2001) fitted with hypocenter distribution (Hasegawa et al., 1994).

In the NEJ-Kuril subduction zone, the depth to the down-dip limit of subduction-type earthquakes (i.e., shallow-angle, thrust-type earthquakes that occur on the plate interface) is about $50 \mathrm{~km}$, which is similar to (or slightly deeper than) those in other subduction zones in the world (i.e., Oleskevich et al., 1999). Many researchers have believed that subduction interface deeper than the $\sim 50 \mathrm{~km}$ down-dip limit is not coupled. However, the observed interseismic subsidence along the Pacific coast (Fig. 6, right) cannot be explained by such shallow coupling (Fig. 7). Our forward model calculations indicate that deep coupling (to a depth $\sim 100 \mathrm{~km}$ ) and a back-slip rate of
$50 \mathrm{~mm} / \mathrm{yr}$ is needed to subside the Pacific coast at a maximum rate $\sim 10 \mathrm{~mm} / \mathrm{yr}$ (Ikeda et al., 2012; Fig. 7).

Recent studies of GPS data inversion have yielded significantly different patterns of slip deficit on the Kuril-Japan trench plate interface. Suwa et al. (2006) indicated that the crustal deformation over the NEJ arc is well reproduced by deep coupling to a depth of $\sim 100 \mathrm{~km}$, whereas Nishimura et al. (2004) and Hashimoto et al. (2009) estimated shallower coupling at seismogenic depths $(0 \sim 50 \mathrm{~km})$. Suwa et al. (2006) assumed dislocation sources only on the plate interface, and attributed all the observed crustal deformation to slip on the plate interface. In this sense, the model of Suwa and others (2006) is identical to our model (Figs 7 and 9). On the other hand, Nishimura et al. (2004) assumed dislocation sources not only on the Pacific side but also on an "incipient collision zone", which was supposed to exist along the Japan Sea coast "absorbing" crustal deformation on the backarc side (west of the volcanic front) of the NEJ are. This is the reason why Nishimura et al. (2004) failed to detect deep coupling on the Kuril-Japan subduction interface. It is not clear why the results of Hashimoto and others (2009) differ from those of Suwa and others (2006) and our results. It should be pointed out, however, that their slip-deficit distribution does not account for the observed rapid subsidence along the Pacific coast, but instead produces rapid uplift along the coast (Supplementary Fig. 2 of Hashimoto et al., 2009) as is predicted by the shallow coupling model of this study (Fig. 7).

\section{Episodic decoupling}

Both horizontal contraction and coastal subsidence in the NEJ arc in interseismic periods result from a common cause; i.e., the dragging force produced by the subducting slab (Fig. 1). The elastic strain that had progressively been built up in and around the NEJ subduction zone until March 11, 2011, was to be eventually released in association with episodic slip on the plate interface that had been coupled so far. However, many seismologists believed, before the Tohoku gigantic earthquake of 2011, that elastic strain due to interseismic coupling should have been released by many subduction-type Mw 7 8 earthquakes that have occurred during the past $\sim 100$ years (Fig. 8, left). Their belief was based on the asperity hypothesis, which assumes decoupled (or very weakly coupled) plate interface outside asperity patches (e.g., Yagi, 2011; Iio and Matsuzawa, 2012). Their belief was based also on an implicit assumption that the strain buildup during the past $\sim 100$ years at high rates should have been mostly inelastic without any sound theoretical or observational justification. 


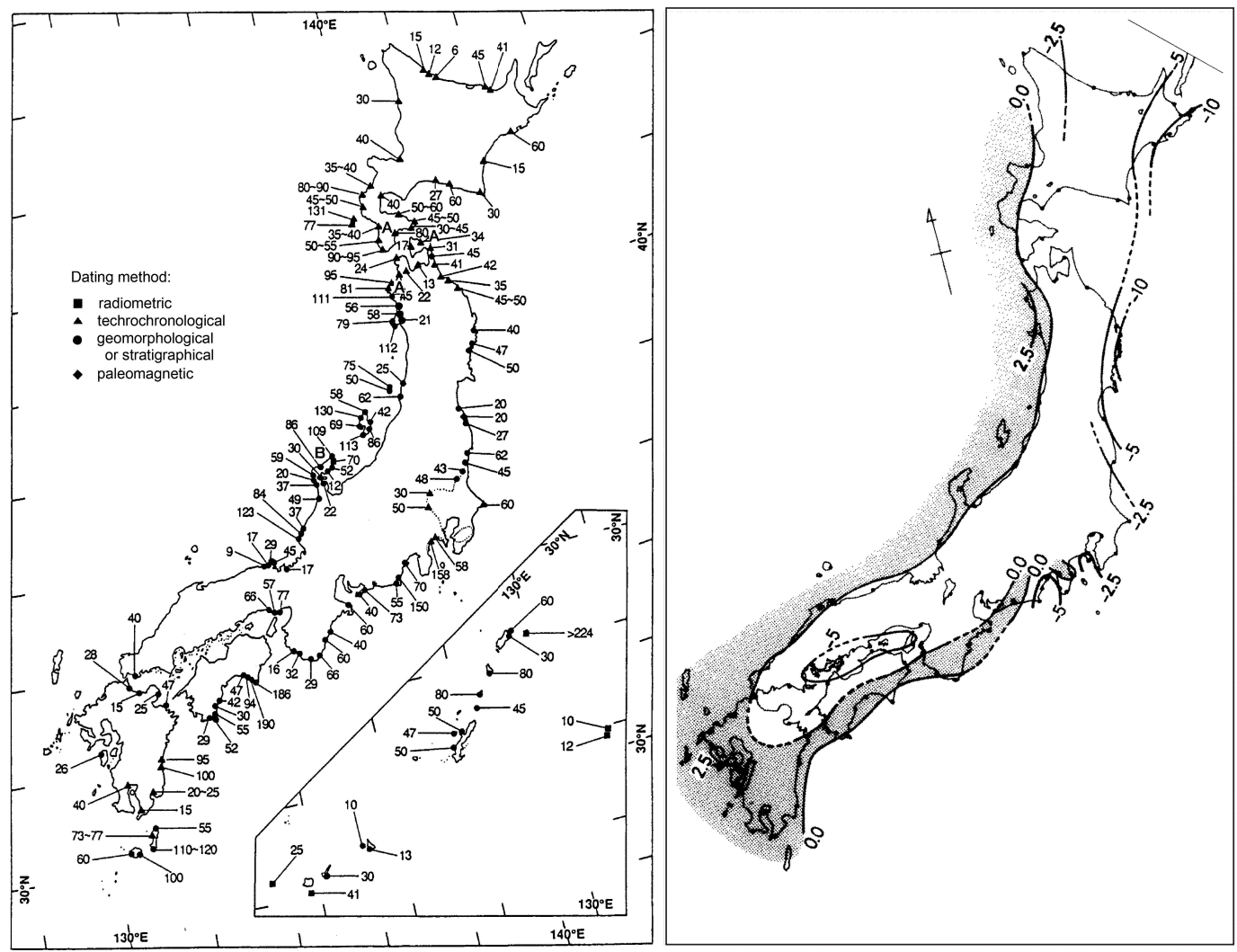

Figure 6. Rates of vertical deformation over the Japan arc on different time scales. [Left] Height distribution (in meters) of Last Interglacial ( 125 ka) shorelines (Ota and Saito, 2001). [Right] Recent vertical crustal movements revealed by tide-gauge observations during the period 1955-1981 (Kato, 1983). Contours indicate rates of uplift (in mm/yr). Shadow indicates uplift. Note that the Pacific coast of NEJ and Hokkaido has been subsiding at extremely high rates (as large as $10 \mathrm{~mm} / \mathrm{yr}$ ), whereas marine terrace data (left figure) indicate moderate rates (0.1-0.5 mm/yr) of uplift.

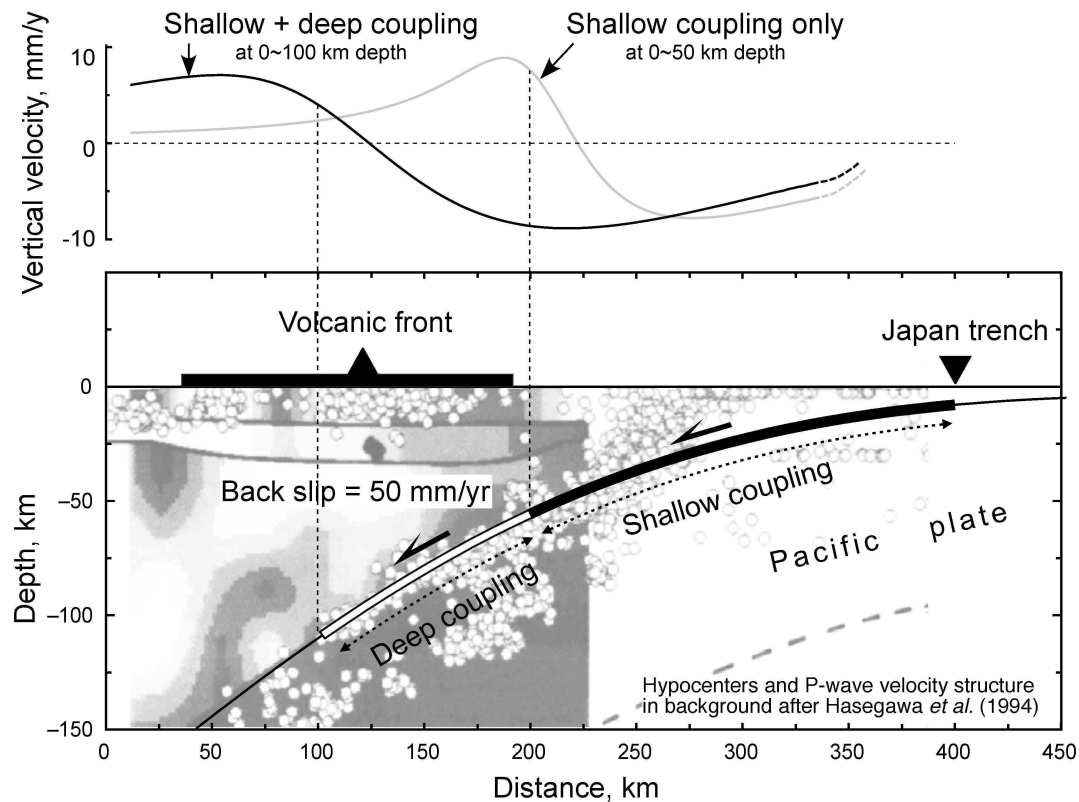

Figure 7. [Top] Calculated patterns of interseismic deformation along a transect crossing the NEJ arc and the Japan Trench (Ikeda et al., 2012). Calculations were performed by using a dislocation fault model in an elastic half space. Gray line curve shows interseismic deformation caused by shallow coupling (thick black line in the bottom figure) on the plate interface at $0 \sim 50 \mathrm{~km}$ depths. Black line curve shows interseismic deformation caused by deep coupling (thick black line plus thick white line in the bottom figure) at 0 100 km depths. A uniform back-slip rate of $\sim 50 \mathrm{~mm} / y$ r over the deeply coupled plate interface is needed to subside the Pacific coast at a maximum rate $\sim 10$ $\mathrm{mm} / \mathrm{yr}$. [Bottom] Geometry of plate interface along the same transect as of the top figure. Earthquake hypocenters and P-wave velocity structure in the background are after Hasegawa et al. (1994) using tomography data by Zhao et al. (1992). 


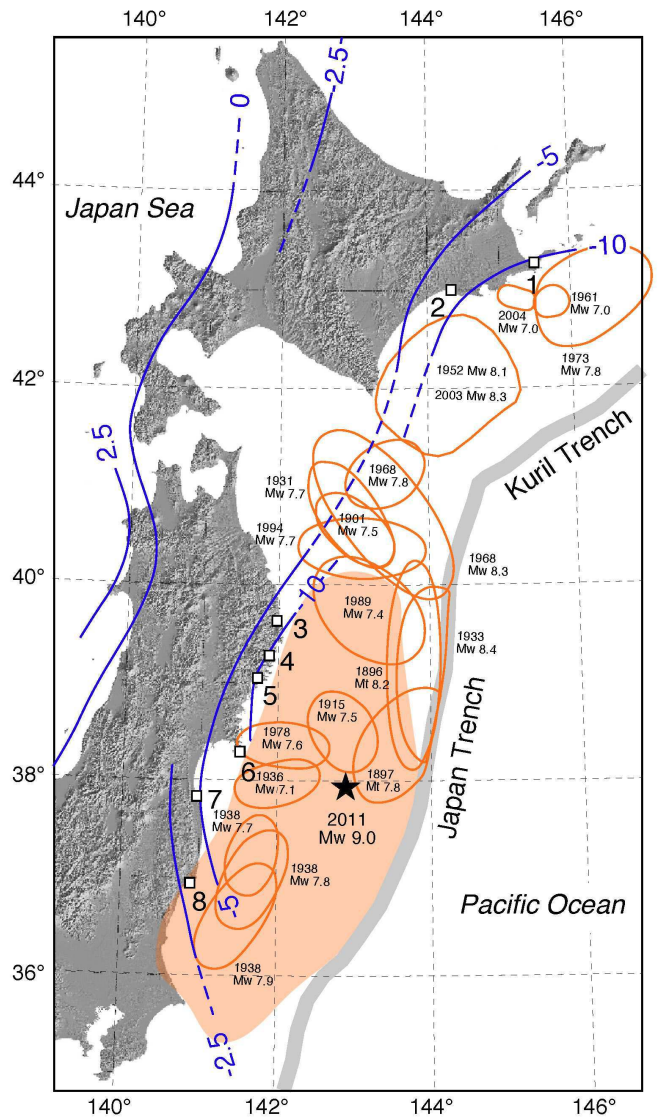

Figure 8. [Left] Map showing recent vertical crustal movements and source areas of large subduction earthquakes (Ikeda et al., 2012). Contour lines (in blue) indicate rates of uplift (in mm/yr) revealed by tide gauge observations during the period 1955-1981 (Kato, 1983). Open ovals indicate source areas of subduction earthquakes of $M w \geq 7.0$ since 1896. The epicenter and source area of the 2011 Tohoku earthquake of Mw 9.0 are indicated by an asterisk and a shaded oval (in orange), respectively. Open squares indicate tide-gauge stations; station numbers correspond to those in the right figure. [Right] Selected tide-gauge records along the Pacific coast (Geographical Information Authority of Japan, 2010). See the left figure for the location of each station. Arrows indicate large earthquakes (Mw $\geq 7.0)$ that occurred near each station. Note progressive subsidence of the Pacific coast at rates as high as 5-10 mm/yr, except for the Onahama station, which has likely been affected by coal mining.

However, tide-gauge records along the Pacific coast have indicated progressive subsidence due to strong drag of the subducting Pacific plate during the past 60-80 years (Fig. 8). It is clearly demonstrated in this figure that subduction earthquakes of $\mathrm{Mw} 7 \sim 8$ during this period had nothing to do with strain release, i.e., uplifting the Pacific coast. Instead, some of these Mw 7 8 earthquakes further enhanced coastal subsidence (Fig. 8, right).

As shown in Figure 8 (left), the source areas of these Mw 7-8 earthquakes are just small patches isolated within the coupled plate interface as wide as $\sim 300 \mathrm{~km}$. (compare Figs 7 and 8.). Slip on such small patches is far from sufficient to cause full strain release, and therefore crustal strain was not effectively released in association with these Mw 7 8 earthquakes. As discussed earlier in this paper, a full strain-release event should have a rupture surface that extends alongdip over the whole width $\left(W_{c}\right)$ of the coupled plate interface and extends along strike for more than 2 3 times as long as $W_{c}$. For instance, the 2003 Tokachi-oki earthquake of Mw 8.3 (for location, see Fig. 3 left) was produced by slip on a rupture surface $\sim 150 \mathrm{~km}$ wide and $\sim 150 \mathrm{~km}$ long; the rupture did not reach the free surface and hence was "closed-ended". For these reasons, it released elastic strain just partially.

\section{The 2011 Tohoku earthquake of Mw 9.0}

\section{Coseismic deformation}

It seemed likely that the 2011 earthquake of Mw 9.0 is a full strain-release event, because its rupture surface $(\sim 500 \mathrm{~km}$ long along strike and $\sim 200 \mathrm{~km}$ wide) encompassed those of previously occurred Mw 7 8 subduction earthquakes (Fig. 8, left). However, the Pacific coast was not uplifted but further subsided by $120 \mathrm{~cm}$ at the maximum (Geographical Information Authority of Japan, 2011). This is because the down-dip limit of the coseismic rupture was $\sim 50 \mathrm{~km}$ deep, and the deeper coupled interface $(50 \sim 100 \mathrm{~km}$ depths) remains still unbroken (Fig. 9). Note again that the down-dip limit of the 2011 coseismic rupture coincides approximately with the maximum depth of previously occurred subduction-type earthquakes in the NEJ-Kuril subduction zone. Then, what will happen on the deeper coupled interface?

\section{Postseismic deformation}

Paleoseismological observations give some insights into the 

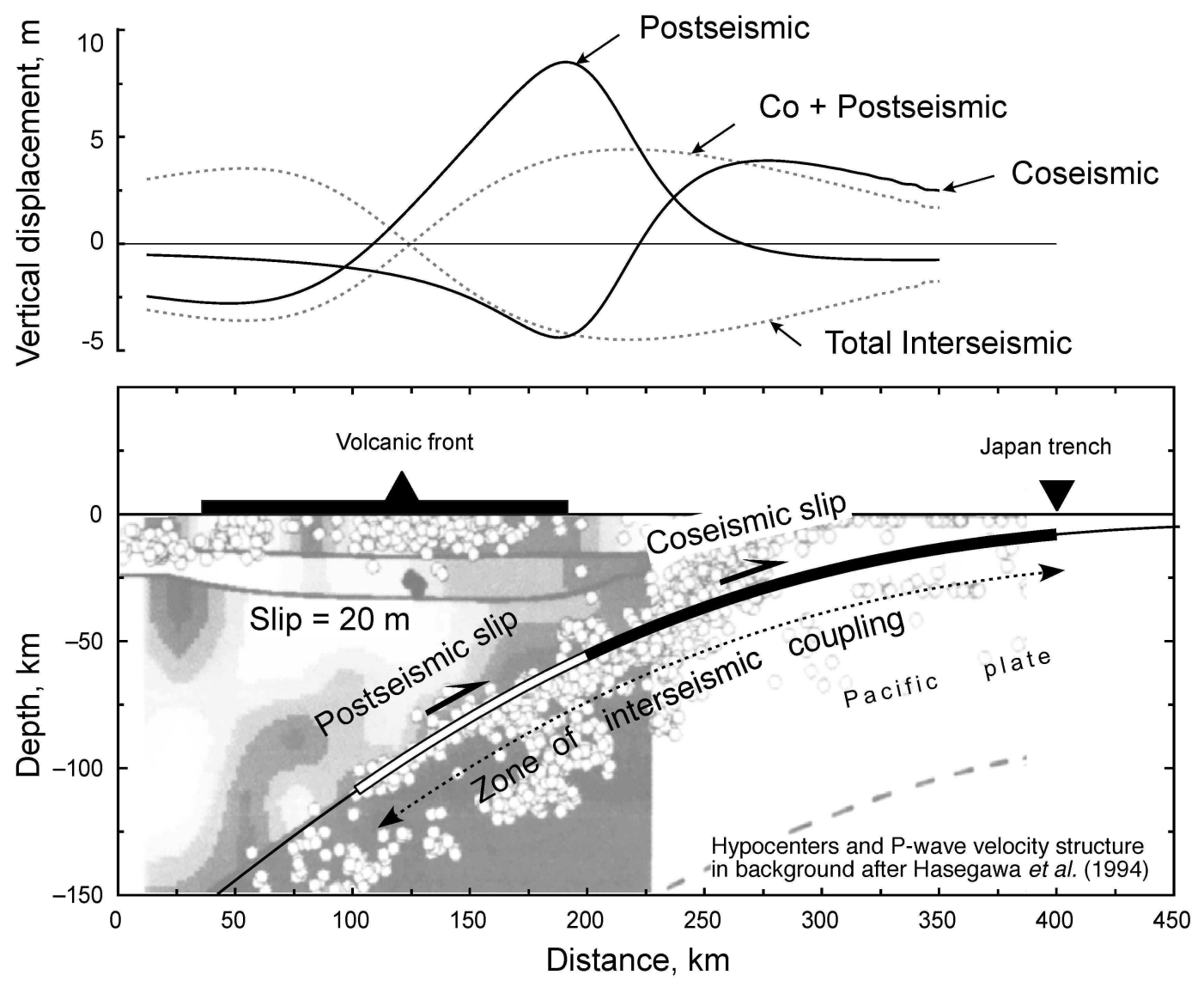

Figure 9. Coseismic, postseismic and interseismic deformation during a whole cycle of strain buildup and release over the Northeast Japan arc-trench system (Ikea et al., 2012). The line of profile and the geometry of plate interface are the same as those in Figure 7. Total amount $(=20 \mathrm{~m})$ of back slip is given over the coupled plate interface at 0-100 km depths; slip is assumed to be uniform (20 meters) over the coupled portions of the plate interface down to $\sim 100 \mathrm{~km}$ depth. Coseismic slip on the shallow plate interface at 0-50 km depths results in coseismic subsidence along the Pacific coast, whereas subsequent aseismic slip at 50-100 km depths causes uplift, thereby cancelling both the interseismic and the coseismic subsidence along the Pacific cast. The 2011 Tohoku event is unique in that the decoupling occurs seismically on the shallower interface (0 50 km depths) and probably aseismically on the deeper interface (50 100 km depths).

decoupling process below seismogenic depths in the NEJ-Kuril subduction zone. Paleo-tsunami and coastal-uplift evidence has indicated the occurrence of a gigantic earthquake off the Pacific coast of Hokkaido in the 17th century (Hirakawa, 2000; Atwater et al., 2004; Nanayama et al., 2003). Atwater et al. (2004) and Sawai et al. (2004) investigated coastal uplift associated with this 17th-century event on the basis of environmental-change analysis using diatom microfossils in tidal-flat sediments, and found that, following the deposition of tsunami sand, the tidal flat was gradually uplifted for tens of years to become emerged.

The above observations suggest that, in the NEJ-Kuril subduction zone, the deep decoupling at 50 100 km depths occurs aseismically following a sudden (i.e., seismic) decoupling event at shallower depths (0 50 km). Simple dislocation calculation (Fig. 9) predicts that aseismic after-slip on the deeper coupled interface would cause uplift along the Pacific coast of the NEJ and eventually would cancel the subsidence that has been accumulated before and during the 2011 Tohoku earthquake (Ikeda et al., 2012).

Uplift along the Pacific coast has been detected by GPS observations at rates of $5 \sim 8 \mathrm{~cm} /$ month during one month after the 2011 earthquake (Geographical Information Authority of Japan, 2011), and is continuing at reduced but quite constant rates $(\sim 1 \mathrm{~cm} / \mathrm{month})$ as of May 2014. Ozawa et al. (2011) analyzed geodetic data in just a short period (10 days) following the 2011 earthquake. Their analysis indicated that, during this short period, after-slip occurred dominantly on the shallower plate interface $(0 \sim 50 \mathrm{~km}$ deep), but significantly on the deeper interface to a depth of 90-100 km beneath the volcanic front (Fig.s 2b and 3 of Ozawa et al., 2011). GPS time-series data in the past 2-3 years clearly indicate constant uplift at a rate of $\sim 1 \mathrm{~cm} /$ month as of May 2014 (Geographical Information Authority of Japan, 2014a, 2014b); the area of the recent uplift extends far inland to the volcanic front, resembling the predicted pattern of vertical movements due to deep after-slip at 50-100 km depths (Fig. 9). Visco-elastic effects, if existed, would decay exponentially with time, but were not significantly detected from recent GPS data.

Although visco-elastic relaxation in the upper mantle may have caused part of the post-2011 vertical deformation in the NEJ arc, it cannot account for the cancellation of the large amount of coastal subsidence that had been built up until and during the 2011 earthquake. Viscosity of the upper mantle causes only a subtle amount of deformation $(<10 \%)$ in total compared with near-field (i.e., near the dislocation source) coseismic deformation, because it just damps the elastic response of the overlying lithosphere due to dislocation within the lithosphere (e.g., Matsu'ura and Tanimoto, 1981). Tide-gauge 
records suggest that the total seismic and interseismic subsidence along the Pacific coast of Tohoku is as large as 5-10 meters on an assumption of 500-1000 year recurrence of Mw 9 events. Such a large amount of deformation can never be cancelled through viscoelastic relaxation. Thus, the only plausible mechanism for causing large postseismic recovery would be after-slip on the deeper part of the subduction interface (Fig. 9).

\section{Gigantic decoupling cycles}

Recurrence interval of gigantic decoupling events from the NEJKuril subduction zone not only is a key to quantitatively understanding the strain buildup-and-release process, but also is crucial to assess earthquake hazards. Studies of tsunami deposits in Sendai-Ishinomaki area first revealed that a tsunami with large inundation depths and distances occurred in association with the AD 869 Jogan earthquake (Minoura and Nakaya, 1991; Minoura et al., 2001; Sawai et al., 2008). The magnitude of the tsunami is similar to that associated with the 2011 earthquake. Therefore, the AD 869 Jogan earthquake could be a predecessor of the 2011 earthquake of Mw 9.0. Hirakawa (2000) examined tsunami deposits at many sites at different altitudes along the Hokkaido coast, and revealed that tsunamis with exceptionally large inundation heights have repeatedly occurred at an average recurrence interval about 500 years. Thus, available data suggest that the recurrence interval of gigantic decoupling events is 500-1100 years. It should be noted, however, that tsunami evidence is not sensitive to discriminating between full and partial strain-release events. More direct evidence is coastal uplift and subsidence, as discussed in the next section.

\section{A global comparison}

A global survey was made of subduction zones that have produced gigantic $(\mathrm{Mw} \geq 9.0)$ earthquakes. It was found that these subduction zones are classified, in terms of coupling-decoupling behavior, into two types: (1) the Northeast Japan type and (2) the Chilean type (Fig. 10; Ikeda et al., 2012).

The Chilean type strain buildup/release process is simple and straightforward in the sense that seismogenic zone (down to a 40-50 km depth) plays everything (Fig. 10a). The source areas of the 1960 Chile, 1964 Alaska, and 1700 Cascadia earthquakes lack evidence for interseismic deep coupling. Paleoseismological evidence indicates interseismic uplift around the down-dip edge of coseismic rupture, where coseismic subsidence is observed (e.g., Atwater, 1987; Atwater et al., 1992; Cisternas et al., 2005; Shennan and Hamilton, 2006). This implies that the deeper plate interface is basically decoupled in interseismic periods, although subtle postseismic slip could exist on a transition zone down-dip of the coseismic rupture (e.g., Wang et al., 2003; Freymueller et al., 2000; Suito and Freymueller, 2009). In the Chilean-type subduction zones, both transitional after slip and visco-elastic relaxation in the upper mantle would cause postseismic coastal uplift. However, such postseismic deformation would be much less in total amount than, and difficult to distinguish from, interseismic coastal uplift due to restored coupling on the plate interface.

On the other hand, the Northeast Japan type strain buildup/release process seems to be exceptional (Fig. 10b). In the Northeast Japan subduction zone, interseismic coupling occurs to a depth as deep as $\sim 100 \mathrm{~km}$. Its decoupling process is two-fold: seismic decoupling occurs only on the shallower plate interface (0 50 km depths) while

\section{(A) Chilean type}

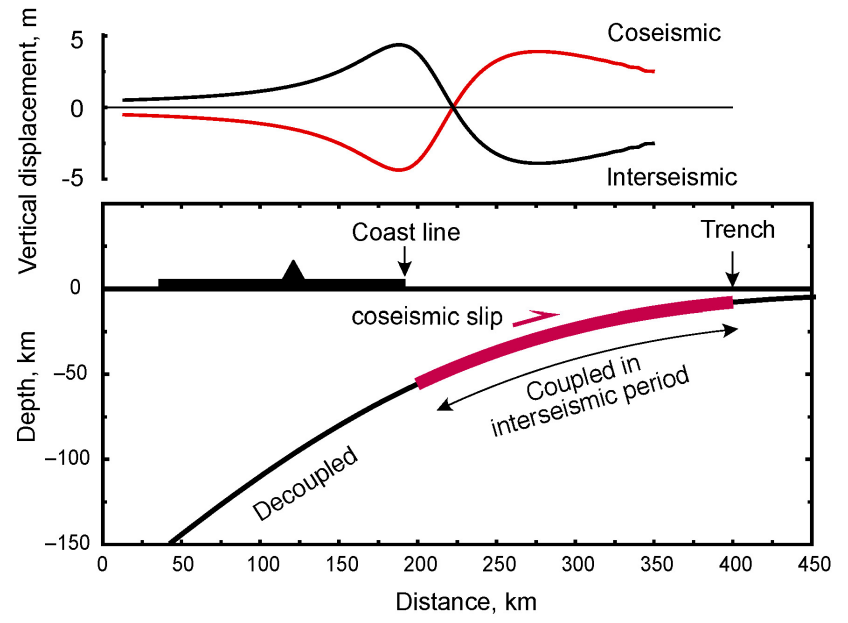

(B) NE Japan type

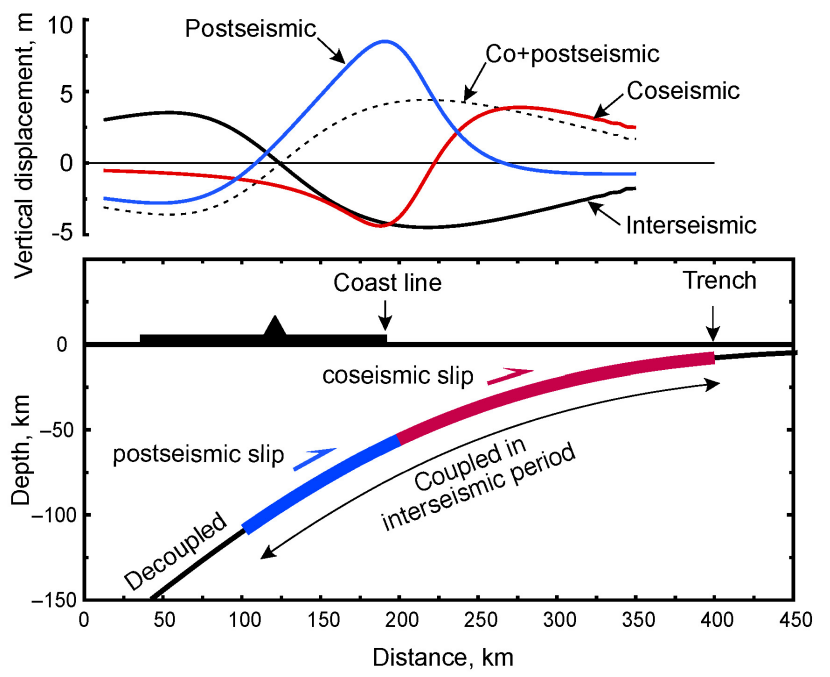

Figure 10. Two types of strain buildup and release at subduction zones that produce gigantic $(M w \geq 9.0)$ subduction earthquakes (Ikeda et al., 2012). The geometry of plate interface and amounts of surface deformation could be arbitrary but are represented in this figure by those of the 2011 Tohoku earthquake (Figures 7 and 9). (A) Chilean type strain buildup/release process. Interseismic deformation is basically opposite to coseismic deformation. (B) Northeast Japan type strain buildup/release process, characterized by deep interseismic coupling to a depth $\sim 100 \mathrm{~km}$. Seismic decoupling occurs only on the shallower plate interface $(0 \sim 50 \mathrm{~km}$ depths), while the deeper interface $(50 \sim 100 \mathrm{~km}$ depths) decouples aseismically following the earthquake. Note that coseismic and postseismic deformation in total is just opposite to total interseismic deformation.

the deeper interface (50 100 km depths) decouples aseismically following the earthquake. Although we do not know the mechanism controlling the complex behavior of the NEJ-Kuril subduction zone, a possible cause for such deep coupling would be thermal. The oceanic lithosphere of the western Pacific is very old and therefore cold, and it has been subducted beneath the NEJ-Kuril arc. The cold slab may affect rheological properties of the plate interface at depth. 
(A)

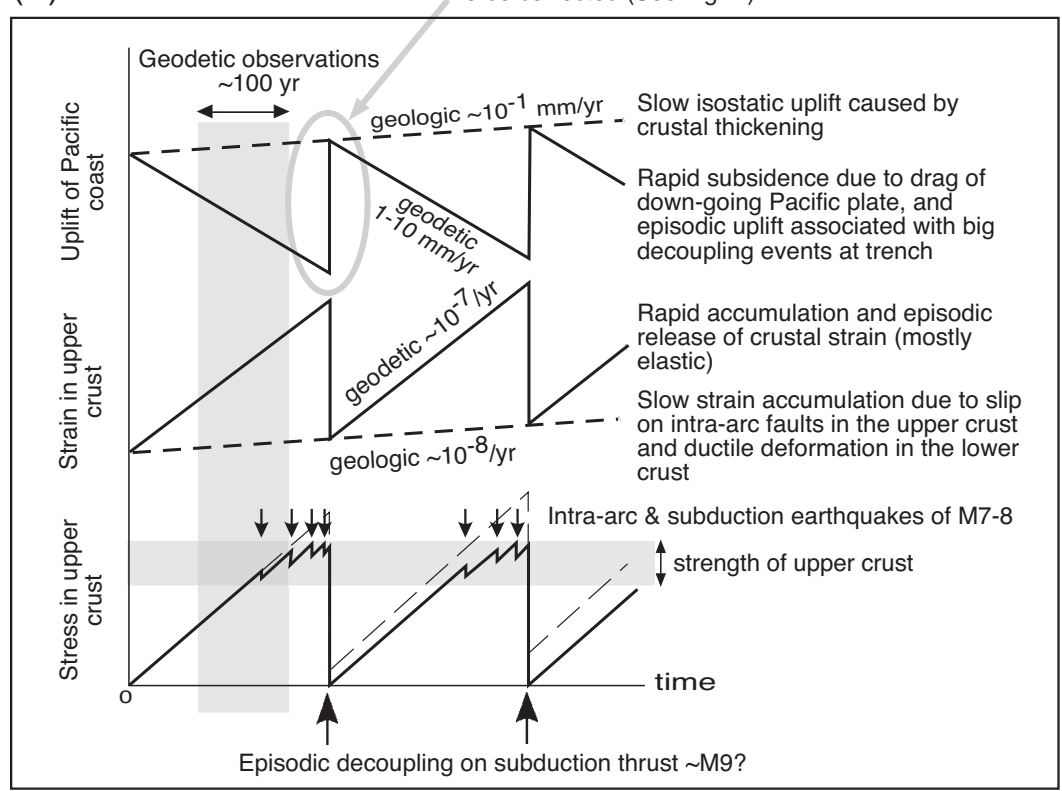

(B)

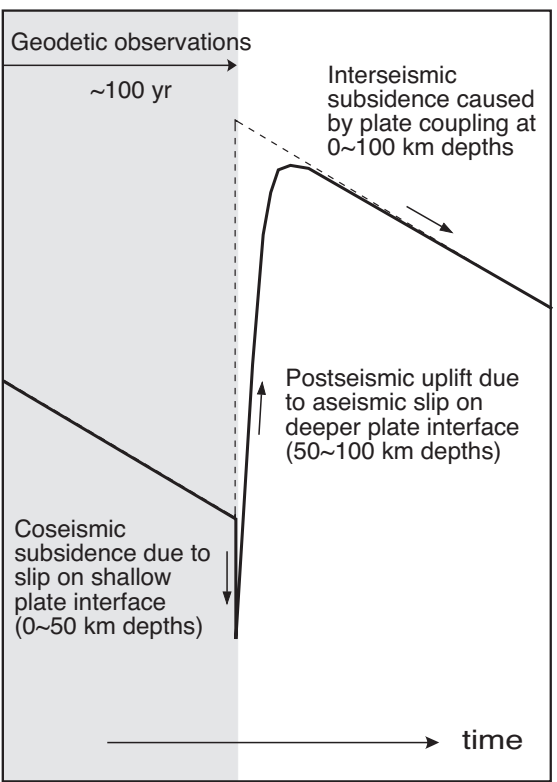

Figure 11. Summary of strain buildup and release in the NEJ arc (Ikeda et al., 2012). (A) The process of strain buildup and release in the NEJ arc proposed by Ikeda (2003, 2005, 2006). A modification is needed for detailed coseismic response. (B) Coseismic response associated with two-fold decoupling. Observations of the 2011 Tohoku earthquake (Mw 9.0) indicated that coseismic slip occurs only on the shallower part (0 50 km depths) of the locked plate interface, resulting in additional coastal subsidence. Following the main shock, aseismic slip occurs on the deeper plate interface (50-100 $\mathrm{km}$ depths), thereby resulting in postseismic coastal uplift.

\section{Conclusions}

There has been a discrepancy between long-term (geologic) and short-term (geodetic) strain observations in both horizontal and vertical directions over the NEJ arc. Geodetic observations in the past $\sim 100$ years have revealed strain accumulation over the NEJ arc at a rate as high as $10^{-7} \mathrm{strain} / \mathrm{yr}$, whereas geologically observed strain rates are one order of magnitude slower (Figs 3, 5 and 11a). A similar discrepancy exists also in vertical movements; tide gauge records along the Pacific coast have indicated subsidence at a rate as high as $\sim 10 \mathrm{~mm} / \mathrm{yr}$ during the last $\sim 80$ years, despite the fact that Late Quaternary marine terraces along the Pacific coast indicate long-term uplift at 0.1-0.5 mm/yr (Figs 6, 8 and 11a). Thus, most of the strain accumulated in the last 100 years at unusually high rates is elastic, and is to be released by slip on the coupled plate interface. Only a fraction $(\sim 10 \%)$ of geodetically-observed crustal shortening is accommodated within the NEJ arc as long-term (inelastic) deformation (Fig. 11a).

In order to release the elastic strain that has been accumulating at high rates, a large slip event is needed. Although a number of large (Mw 7 8) subduction earthquakes have occurred in the past $\sim 100$ years, they had nothing to do with strain release or coastal uplift (Fig. 8 ); this is because their rupture areas were only small isolated patches in the $\sim 300 \mathrm{~km}$ wide zone of coupled plate interface (Figs. 7 and 8 left). The 2011 earthquake of Mw 9.0, whose rupture surface encompassed those of previously occurred Mw 7-8 earthquakes, is likely to be such a decoupling event that effectively releases elastic strain due to plate coupling. However, at 50 100 km depths downdip of the 2011 rupture, there still exists a coupled part of plate interface, on which a large amount of aseismic after-slip may occur in the coming decades (Fig. 11b).
We conclude that a full elastic-strain-release event on the NEJKuril subduction zone is two-fold: seismic slip on the shallower plate interface (0 50 km deep), and aseismic slip on the deeper interface (50 100 km deep) following the seismic slip (Figs 9, 10b, 11b). The two-fold decoupling behavior of the NEJ-Kuril subduction zone could be unique. A global survey was made of other subduction zones that produced gigantic $(\mathrm{Mw} \geq 9.0)$ earthquakes, but no such deep coupling was found (Fig. 10a).

\section{Acknowledgements}

I would like to thank Yujiro Ogawa and Yildirim Dilek for their editorial comments and suggestions on the manuscript, and Kiichiro Kawamura and Teruyuki Kato for reviewing the manuscript. This paper benefited greatly from many in-depth comments by Teruyuki Kato.

\section{References}

Atwater, B.F., 1987, Evidence for great Holocene earthquakes along the outer coast of Washington State: Science, v. 236, pp. 942-944.

Atwater, B.F., Jiménez, N.H. and Vita-Finzi, C., 1992, Net late Holocene emergence despite earthquake-induced submergence, south-central Chile: Quaternary International, v. 15/16, pp. 77--85.

Atwater, B.F., Furukawa R., Hemphill-Haley, E., Ikeda Y., Kashima K., Kawase K., Kelsey, H.M., Moore, A.L., Nanayama F., Nishimura Y., Odagiri S., Ota Y., Park S.C., Satake K., Sawai Y., and Shimokawa K., 2004, Seventeenth-century uplift in eastern Hokkaido, Japan: Holocene, v. 14 , pp. $487-501$.

Bilham, R., Engdahl, E.R., Feldl, N., and Satyabala, S.P., 2005, Partial and complete rupture of the Indo-Andaman plate boundary 1847-2004: Seismological Research Letters, v. 76, pp. 299-311, doi: 10.1785/ gssrl.76.3.299. 
Cisternas, M., Atwater, B.F., Torrejon, F., Sawai, Y., Machuca, G., Lagos, M., Eipert, A., Youlton, C., Salgado1, I., Kamataki, T., Shishikura, M., Rajendran, C.P., Malik, J.K., Rizal, Y. and Husni, M., 2005, Predecessors of the giant 1960 Chile earthquake: Nature, v. 437, pp. 404-407.

Freymueller, J.T., Cohen, S.C., Fletcher, H.J., 2000, Spatial variations in present-day deformation, Kenai Peninsula, Alaska, and their implications: Journal of Geophysical Research, v. 105, pp. 8079-8101.

Fujii, Y., and Matu'ura, M., 2000, Regional difference in scaling laws for large earthquakes and its tectonic implication: Pure and Applied Geophysics, v. 157, pp. 2283-2302.

Geist, E. and Dmowska, R., 1999, Local tsunamis and distributed slip at the source: Pure and Applied Geophysics, v. 154, pp. 485-512.

Geographical Information Authority of Japan, 2010, Crustal deformation of entire Japan: Report of the Coordinating Committee for Earthquake Prediction, v. 84, pp. 8-31 (in Japanese).

Geographical Information Authority of Japan, 2011, Crustal movements in the Tohoku district: Report of the Coordinating Committee for Earthquake Prediction, v. 86, pp. 184-272 (in Japanese).

Geographical Information Authority of Japan, 2014a, Crustal movements in the Tohoku district: Report of the Coordinating Committee for Earthquake Prediction, v. 91, pp. 77-104 (in Japanese).

Geographical Survey Institute, 2014b, Crustal movements in the Tohoku district: Report distributed at the 203rd Coordinate Committee on the Earthquake Prediction, May 19, 2014.

Goldfinger, C., Ikeda, Y., Yeats, R.S., and Ren, J., 2013, Superquakes and supercycles: Seismological Research Letters, v. 84, n. 1, pp. 24-32, doi: $10.1785 / 0220110135$.

Hasegawa, A., Horiuchi, S., and Umino, N., 1994, Seismic structure of the northeastern Japan convergent margin: A synthesis: Journal of Geophysical Research, v. 99, pp. 22,295-22,311.

Hashimoto, C., Noda, A., Sagiya, T., and Matsu'ura, M., 2009, Interplateseismogenic zones along the Kuril-Japan trench inferred from GPS data inversion, Nature Geoscience, v. 2, 141-144.

Hirakawa, K., Nakamura, Y. and Haraguchi, T., 2000, Gigantic tsunamis along the Pacific coast of Hokkaido and their recurrence intervals: The Earth Monthly, Spec. Issue, v. 28, pp. 154-161 (in Japanese).

Iio, Y., and Matsuzawa, T., 2012, The generation process of the Tohoku earthquake: Why did the magnitude 9 event occur?: Journal of the Geological Society of Japan, v. 118, 248-277, doi: 10.5575/geosoc.2012. 0023 (in Japanese with English Abstract).

Ikeda, Y., 1996, Implications of active fault study for the present-day tectonics of the Japan arc: Active Fault Research, v. 15, pp. 93-99 (in Japanese with English Abstract).

Ikeda Y., 2005, Long-term and short-term rates of horizontal shortening over the Northeast Japan arc: Hokudan International Symposium on Active Faulting, Hokudan City, Japan, January 17-24, 2005, Program and Abstracts, pp. 48-49.

Ikeda Y., 2006, Long-term and short-term rates of crustal deformation over the northeast Japan arc, and their implications for gigantic earthquakes at the Japan Trench: International Workshop on Tectonics of Plate Convergence Zones, University of Tokyo, Sep. 28-29, 2006, Program and Abstracts, pp. 64-68.

Ikeda, Y., Okada, S., and Tajikara, M., 2012, Long-term strain buildup in the Northeast Japan arc-trench system and its implications for gigantic strainrelease events: Journal of the Geological Society of Japan, v. 118, pp. 294-312, doi: 10.5575/geosoc.2012.0018 (in Japanese with English Abstract).

Iwasaki, T., Kato, W., Moriya, T., Hasemi, A., Umino, N., Okada, T., Miyashita, K., Mizogami, T., Takeda, T., Sekine, S., Matsushima, T., Tashiro, K., and Miyamachi, H., 2001, Extensional structure in northern Honshu arc as inferred from seismic refraction/wide-angle reflection profiling: Geophysical Research Letters, v. 28, pp. 2329-2332.

Kaneoka, I., Takigami, Y., Takaoka, N., Yamashita, S., and Tamaki, K., 1992, 40Ar-39Ar analysis of volcanic rocks recovered from the Japan Sea floor: constraints on the age of formation of the Japan Sea: Proceedings of the Ocean Drilling Program, Scientific Results, v. 127/128, Pt. 2, pp. 819-836.
Kato, T. and Tsumura, K. (1979). "Vertical land movement in Japan as deduced from tidal record (1951-1978),” Bull. Earthquake Res. Inst., v. 54, pp. 559-628 (in Japanese with English Abstract).

Kato, T., 1983, Secular and earthquake-related vertical crustal movements in Japan as deduced from tidal records (1951-1981): Tectonophysics, v. 97, pp. 183-200.

Koike, K., and Machida, H., eds, 2001, Atlas of Quaternary Marine Terraces in the Japanese Islands: University of Tokyo Press (in Japanese).

Le Pichon, X., and Sibuet, J.C., 1981: Passive margins - a model of formation: Journal of Geophysical Research, v. 86, pp. 3708-3720.

Matsuda, T., Nakamura, K., and Sugimura, A., 1967, Late Cenozoic orogeny in Japan: Tectonophysics, v. 4, pp. 349-366.

Matsu'ura, M., and Sato, T., 1997, Loading mechanism and scaling relations of large interpolate earthquakes: Tectonophysics, v. 227, pp. 189-198.

Matsu'ura, M. and Tanimoto, T., 1981, Quasi-static displacements due to faulting in a layered half-space with an intervenient visco-elastic layer: Journal of Physics of the Earth, v. 29, 23-54.

McKenzie, D., 1978, Some remarks on development of sedimentary basins: Earth and Planetary Science Letters, v. 40, pp. 25-32.

Minoura, K., Imamura, F., Sugawara, D., Kono, Y., and Iwashita, T., 2001, The 869 Jogan tsunami deposit and recurrence interval of large scale tsunami on the Pacific coast of northeastern Japan: Journal of Natural Disaster Science, v. 23, pp. 83-88.

Minoura, K., and Nakaya, S., 1991, Traces of tsunami preserved in intertidal lacustrine and marsh deposits: Some examples from northeast Japan: Journal of Geology, v. 99, pp. 265-287.

Moriya, S., Chinzei, K., Nakajima, T., and Danhara, T., 2008, Uplift of the Dewa Hills recorded in the Pliocene paleogeographic change of the western Shinjobasin, Yamagata Prefecture: Journal of the Geological Society of Japan, v. 114, pp. 389-304 (in Japanese with English abstract).

Nakane, K., 1973, Horizontal tectonic strain in Japan (I) and (II): Journal of the Geodetic Society of Japan, v. 19, pp. 190-199 and 200-208 (in Japanese with English abstract).

Nanayama, F., Satake, K., Furukawa, R., Shimokawa, K., Atwater, B.F., Shigeno, K., and Yamaki, S., 2003, Unusually large earthquakes inferred from tsunami deposits along the Kuril trench: Nature, v. 424, pp. 660663.

Nishimura, T., Hirasawa, T., Miyazaki, S., Sagiya, T., Tada, T., Miura, S., and Tanaka, K., 2004, Temporal change of interplate coupling in northeastern Japan during 1995-2002 estimated from continuous GPS observations: Geophysical Journal International, v. 157, 901-916.

Okada, S., and Ikeda, Y., 2012, Quantifying crustal extension and shortening in the back-arc region of Northeast Japan: Journal of Geophysical Research, v.117, B01404, doi: 10.1029/2011JB008355.

Oleskevich, D.A., Hyndman, R.D., and Wang, K., 1999, Theupdip and downdip limits to great subduction earthquakes: Thermal and structural models of Cascadia, south Alaska, SW Japan, and Chile: Journal of Geophysical Research, v. 104, pp. 14,965-14,991, doi: 10.1029/ 1999JB900060.

Ota, Y., and Saito, K., 2001, Terrace topography, in Yonekura, N., Kaizuka, S., Nogami, M., and Chinzei, K., eds, Regional Geomorphology of the Japanese Islands, Volume 1: University of Tokyo Press, Tokyo, Japan, pp. 222-237 (in Japanese).

Otofuji, Y., Matsuda, T., and Nohda, S., 1985, Opening mode of the Japan Sea inferred from the palaeomagnetism of the Japan arc: Nature, v. 317, pp. 603-604.

Ozawa, S., Nishimura, T., Suito, H., Kobayashi, T., Tobita, M., and Imakiire, T., 2011, Coseismic and postseismic slip of the 2011 magnitude- 9 TohokuOki earthquake: Nature, v. 745, 373-377, doi:10.1038/nature10227.

Rudnicki, W., and Wu, M., 1995, Mechanics of dip-slip faulting in an elastic half-space: Journal of Geophysical Research, v. 100, pp. 22,173-22,186.

Ruff, L., and Kanamori, H., 1980, Seismicity and the subduction process:Physics of the Earth and Planetary Interiors, v. 23, pp. 240-252.

Sagiya T., Miyazaki, S., and Tada, T., 2000, Continuous GPS array and presentday crustal deformation of Japan: Pure and Applied Geophysics, v. 157, pp. 2303-2322. 
Sato, H., 1989, Degree of deformation of late Cenozoic strata in the northeast Honshu arc: Memoirs of the Geological Society of Japan, v. 32, pp. 257268 (in Japanese with English abstract).

Sato, H., 1994, The relationship between Late Cenozoic tectonic events and stress-field and basin development in northeast Japan: Journal of Geophysical Research, v. 99, pp. 22261-22274.

Sato, H., and Amano, K., 1991, Relationship between tectonics, volcanism, sedimentation and basin development, Late Cenozoic, central part of northern Honshu, Japan: Sedimentary Geology, v. 74, pp. 323-343.

Sato, H., Yoshida, T., Iwasaki, T., Sato, T., Ikeda, Y., and Umino, N., 2004, Late Cenozoic tectonic development of the back arc region of central northern Honshu, Japan, revealed by recent deep seismic profiling: Journal of the Japanese Association of Petroleum Technology, v. 69, pp. 145-154 (in Japanese with English abstract).

Savage, J. C., 1983, A dislocation model of strain accumulation and release at a subduction zone: Journal of Geophysical Research, v. 88, pp. 49844996.

Sawai, Y., Satake, K., Kamataki, T., Nasu, H., Shishikura, M., Atwater, B.F., Horton, B.P., Kelsey, H.M., Nagumo, T., and Yamaguchi, M., 2004, Transient uplift after a 17th-century earthquake along the Kuril subduction zone: Science, v. 306, pp. 1918-1920, doi: 10.1126/science.1104895.

Sawai, Y., Shishikura, M., and Komatsubara, J., 2008, A study on paleotsunami using hand corer in Sendai plain (Sendai City, Natori City, Iwanuma City, Watari Town, Yamamoto Town), Miyagi, Japan: Annual Report on Active Fault and Paleoearthquake Researches, Geological Survey of Japan, AIST, n. 8, pp. 17-70 (in Japanese with English abstract).

Shennan, I., and Hamilton, S., 2006, Coseismic and pre-seismic subsidence associated with great earthquakes in Alaska: Quaternary Science Reviews, v. 25 , pp. $1-8$.

Shimamoto, T., 1989, Rheology of rocks and plate tectonics: From rigid plates to deforming plates: Kagaku, v. 59, pp. 170-180 (in Japanese).

Shimazaki, K., 1974, Pre-seismic crustal deformation caused by an underthrusting oceanic plate, in eastern Hokkaido, Japan: Physics of the Earth and Planetary Interiors, v. 8, pp. 148-157.
Suito, H., and Freymueller, J.T., 2009, A viscoelastic and afterslippostseismic deformation model for the 1964 Alaska earthquake: Journal of Geophysical Research, v. 114, B11404, doi: 10.1029/2008JB005954.

Suwa, Y., Miura, S., Hasegawa, A., Sato, T., and Tachibana, K., 2006, Interplate coupling beneath NE Japan inferred from three-dimensional displacement field: Journal of Geophysical Research, v. 111, B04402.

Tajikara M., 2004, Vertical Crustal Movements of the Northeast Japan Arc in Late Quaternary Time: Dr. Thesis, University of Tokyo, 159 pp.

Tamaki, K., Suyehiro, K., Allan, Ingle, J.C. Jr., and Pisciotto, K.A., 1992, Tectonic synthesis and implications of the Japan Sea ODP drilling: Proceedings of the Ocean Drilling Program, Scientific Results, v. 127/ 128, pt. 2, pp. 1333-1348.

Wang, K., Wells, R., Mazzotti, S., Hyndman, R.D., and Sagiya, T., 2003, A revised dislocation model of interseismic deformation of the Cascadia subduction zone: Journal of Geophysical Research, v. 108, 2026, doi: 10.1029/2001JB001227.

Watts, A.B., 2001, Isostasy and Flexure of the Lithosphere: Cambridge University Press, 458 pp.

Weissel, J.K., and Karner, G.D., 1989, Flexural uplift of rift flanks due to mechanical unloading of the lithosphere during extension: Journal of Geophysical Research, v. 94, pp. 13919-13950.

Wu, M., Rudnicki, J.W., Kuo, C.H., and Keer, L.M., 1991, Surface deformation and energy release rates for constant stress drops lip zones in an elastic half-space: Journal of Geophysical Research, v. 96, pp. 16,509-16,524.

Yagi, Y., 2011, Enhance ocean-floor observation: Nature, v. 473, pp. 147148.

Yoshida, T., Ohguchi, T., and Abe, T., 1995, Structure and evolution of source area of the Cenozoic volcanic rocks in northeast Honshu arc, Japan: Memoirs of the Geological Society of Japan, v. 44, pp. 263-308 (in Japanese with English abstract).

Zhao, D., Hasegawa, A., and Horiuchi, S., 1992, Tomographic imaging of P and $\mathrm{S}$ wave velocity structure beneath northeastern Japan: Journal of Geophysical Research, v. 97, pp. 19,909-19,928. 